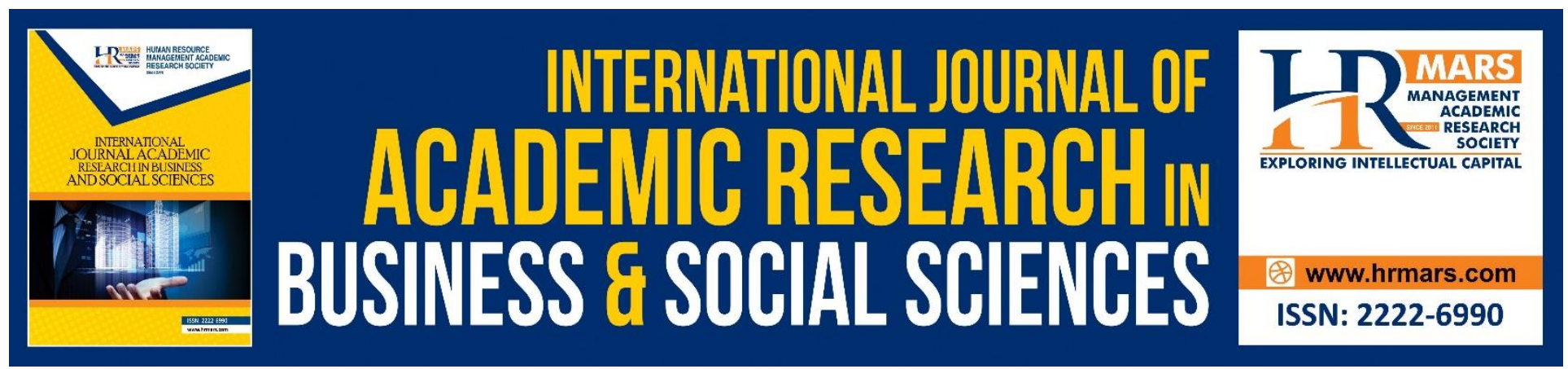

\title{
Validity and Reliability of Assessment Instruments for Special Needs Students (AISNS) Based on Invasion Category Games in Physical Education
}

Faizal Hakimi Bin Samsudin, Mohd Izwan Bin Shahril, Norkhalid Bin Salimin

To Link this Article: http://dx.doi.org/10.6007/IJARBSS/v10-i9/7769

DOI:10.6007/IJARBSS/v10-i9/7769

Received: 25 June 2020, Revised: 27 July 2020, Accepted: 18 August 2020

Published Online: 23 September 2020

In-Text Citation: (Samsudin, Shahril, Salimin, 2020)

To Cite this Article: Samsudin, F. H. B., Shahril, M. I. B., Salimin, N. B. (2020). Validity and Reliability of Assessment Instruments for Special Needs Students (AISNS) Based on Invasion Category Games in Physical Education. International Journal of Academic Research in Business and Social Sciences. 10(9), 414-424.

\section{Copyright: (c) 2020 The Author(s)}

Published by Human Resource Management Academic Research Society (www.hrmars.com)

This article is published under the Creative Commons Attribution (CC BY 4.0) license. Anyone may reproduce, distribute, translate and create derivative works of this article (for both commercial and non-commercial purposes), subject to full attribution to the original publication and authors. The full terms of this license may be seen at: http://creativecommons.org/licences/by/4.0/legalcode

Vol. 10, No. 9, 2020, Pg. 414 - 424

Full Terms \& Conditions of access and use can be found at http://hrmars.com/index.php/pages/detail/publication-ethics 


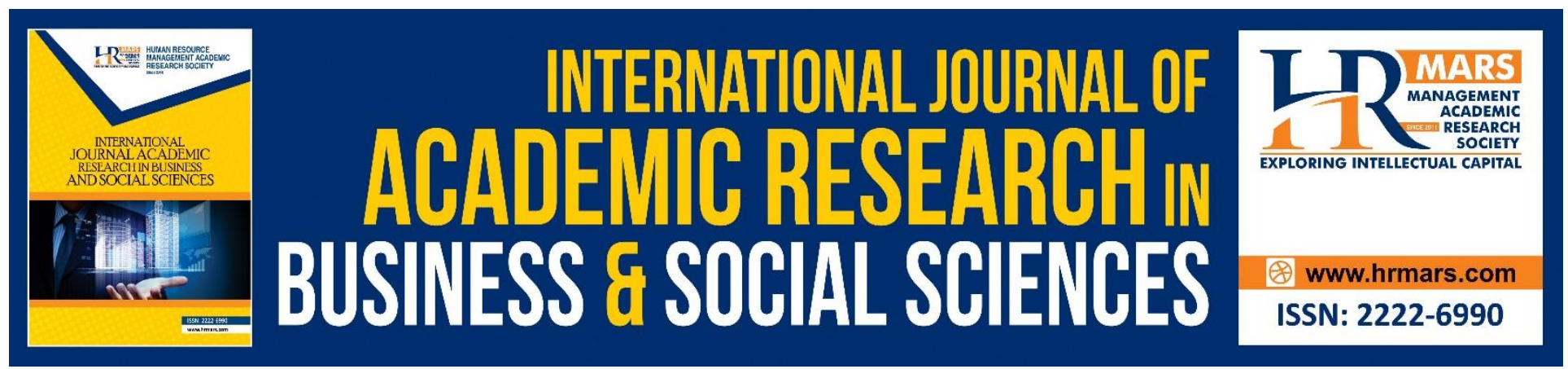

\title{
Validity and Reliability of Assessment Instruments for Special Needs Students (AISNS) Based on Invasion Category Games in Physical Education
}

\section{Faizal Hakimi Bin Samsudin, Mohd Izwan Bin Shahril, Norkhalid Bin Salimin}

Faculty of Sports Science and Coaching, Universiti Pendidikan Sultan Idris

\begin{abstract}
The aim of this study is to determine the validity and reliability of Assessment Instrument for Special Needs Students (AISNS) based on invasion category games in Physical Education. The design of assessment instrument is based on the PDCA Cycle Model (plan, do, check, act). The process of gaining validity and reliability involves two cycles. The result showed the validity of assessment instrument is $r=0.91(N=5)$ while the reliability is $r=0.97(N=6)$. Based on the findings, AISNS is suitable to be used as a standardized learning assessment instrument to assess the level of Performance Standard for basic skills of invasion category games in Physical Education (Special Education) for Form 2.
\end{abstract}

Keywords: Learning Assessment Instrument, School-Based Assessment, Physical Education, Special Education, Invasion Category Games, Validity, Reliability.

\section{Introduction}

Education in Malaysia is an ongoing effort towards further developing the potential of individuals in a holistic and integrated manner, so as to produce individuals, who are intellectually, spiritually, emotionally and physically balanced and harmonious, based on a firm belief in and devotion to God (Curriculum Development Division, 2016). The statement quoted in the National Education Philosophy clearly shows the commitment by the government in its efforts to enhance the educational status.

The educational equality that is planned and implemented involves all students including special needs students. The statement can be referenced in the National Education Policy statements:

Special education is designed to meet the educational needs of special needs students who have been identified as having disabilities, hearing disabilities, learning problems, physical disabilities and various disabilities at the preschool, primary, secondary and post-secondary levels. Education for special needs students is implemented in special education schools, Integrated Special Education Programs and Inclusive Education Programs. At the secondary level, the Ministry of Education (MOE) 
INTERNATIONAL JOURNAL OF ACADEMIC RESEARCH IN BUSINESS AND SOCIAL SCIENCES Vol. 10, No. 9, 2020, E-ISSN: 2222-6990 @ 2020 HRMARS

provides academic or vocational based education for special needs students (Ministry of Education Malaysia, 2018).

The Integrated Special Education Program (ISEP) was introduced in 1962 for selected primary and secondary school. This program was created for several purposes. All students with special educational needs (SSEN) have the opportunity to receive relevant and appropriate educational access. In addition, all SSEN have the opportunity to develop their talents and potential through vocational education to produce skilled people towards improving the quality of life. Students with special educational needs have the opportunity to participate in early intervention programme so that their ability level can be optimized. Finally, ISEP also provides an opportunity for SSEN to participate in educational programs to produce highly skilled groups and potential SSEN could join in the mainstream classes (Ministry of Education Malaysia, 2018).

The MOE has transformed the examination-oriented assessments into holistic, balanced, flexible, fair and refers to the standard. School-Based Assessment (SBA) not only assesses the cognitive intelligence but also includes the emotional intelligence, physical fitness and values and morals contained in the National Education Philosophy. In this regard, the Standard Curriculum for Primary School was implemented in 2011 and introduced the Standard Curriculum for Secondary School in 2017 (Ministry of Education Malaysia, 2013). This curriculum has applied SBA to assess student learning. In the implementation of SBA, formative assessment or assessment for learning is emphasized to enhance student learning and to build on the full potential of students (Na'imah, 2011).

School-Based Assessment is a holistic assessment that consists of two categories, academic and nonacademic. The academic category comprises two components: central assessment and school assessment, while the non-academic category consists of two other components, physical activity assessment, sports and co-curriculum and psychometric assessment (Curriculum Development Division, 2018).

\section{The Objectives of the Study are as Folow}

- To determine the validity of Assessment Instrument for Special Needs Students (AISNS) based on invasion category games in Physical Education among Form 2 students.

- To determine the reliability of Assessment Instrument for Special Needs Students (AISNS) based on invasion category games in Physical Education among Form 2 students.

\section{Learning Assessment Issues in Physical Education (Special Education)}

According to a preliminary report on the Malaysia Education Development Plan (MEDP) $2013-2025$, teachers still do not fully understand the changes occur about the SBA (Ministry of Education Malaysia, 2013). Teachers are lacking information about SBA (Malaysian Examinations Board, 2014). The findings by Arsaythamby, Hariharan \& Ruzlan (2015) also indicate that teachers are still unclear in various aspects of learning assessment including the purpose, time of implementation, implementation techniques, observation, gathering, recording, interpreting and using assessment information to make relevant decisions during teaching and learning session. 
INTERNATIONAL JOURNAL OF ACADEMIC RESEARCH IN BUSINESS AND SOCIAL SCIENCES Vol. 10, No. 9, 2020, E-ISSN: 2222-6990 @ 2020 HRMARS

In addition, the implementation of SBA has increased the workload among teachers (Malaysian Examinations Board, 2013). In order to implement SBA, finding shows that the increasing workload among teacher is due to the large file management (Malaysian Examinations Board, 2014). In response to this study, respondents from teachers in the states of Selangor, Kuala Lumpur and Perak have suggested that the management of evidences for SBA should be simplified.

The Integrated Special Education Program (ISEP) need teachers who qualified in teaching special education (Special Education Division, 2015). However, according to the (Ministry of Education Malaysia, 2013), ISEP is experiencing the lack of qualified teachers. In addition to these issues, the ISEP also faced the lack of options teachers in Physical Education (PE) to teach this subject. In Perak, out of the 233 teachers who teach PE, only 10 teachers are qualified in PE (Special Education Unit, 2018). This situation is contrary to the findings of the study which suggest that PE in secondary schools should be taught by teachers who are graduates in PE (Julismah \& Syed, 2012).

Teachers also have difficulty in formulating learning assessment instruments for school assessment components (Ministry of Education Malaysia, 2013). The findings from Malaysian Examinations Board (2014) shows that teachers are still unclear to use standard performance documents. Respondents also suggested that standard performance documents should be simple and user-friendly. This problem can cause inaccurate assessments and the achievement of the SBA goals will be affected.

There were insufficient sources of reference for SBA and learning assessment instruments. This feedback was derived from the findings of a study involving teachers in the eastern zone, Sabah and Sarawak (Malaysian Examinations Board, 2014). Although provided with reference sources such as textbooks, assessment tools are not holistic and incomplete based on the Standard Document of Curriculum and Assessment (Liza, 2017). Lack of references cause teachers to implement learning assessment processes based on their own knowledge and understanding.

Based on these concerns, researchers have taken the initiative to develop AISNS for SSEN. Quality learning assessment is expected to provide accurate information on student performance and to help teachers make improvements for the purpose of improving teaching and learning (Fakhri \& Mohd, 2016).

\section{Assessment Instrument for Special Needs Students}

Figure 1 shows the theoretical framework used by researchers in developing the learning assessment instruments for invasion games in Physical Education. Assessment Instrument for Special Needs Students (AISNS) is developed to test three main domains which are psychomotor, cognitive and affective. The researcher used seven resources which include theories that act as strong foundation in developing this instrument. Those resources are Constructivism Theory, Revise Bloom's Taxonomy and Humanism Theory. In order to produce instruments that are parallel to the requirements set by the MOE, the researchers refer to the Circular Letter by MOE and Malaysian Examination Board, Standard Document of Curriculum and Assessment on Physical Education (Special Education), Physical Education (Special Education) Text Book and Teaching Games for Understanding (TGfU) model. 


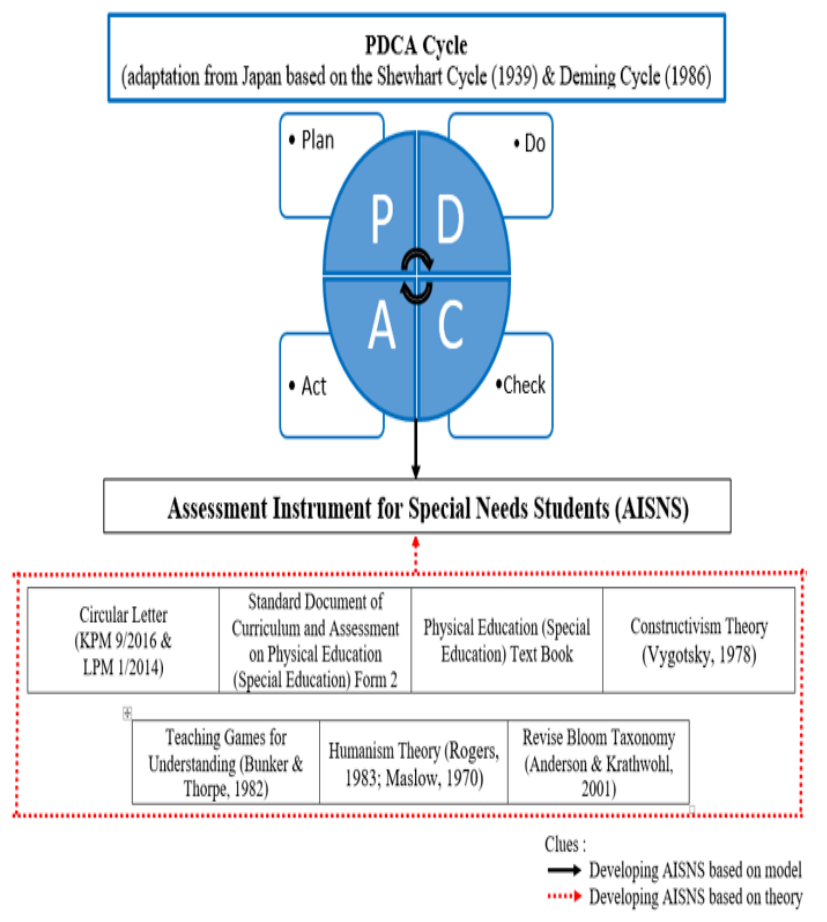

Figure 1: Theoretical Framework

The design of AISNS is based on the PDCA Cycle model. The PDCA Cycle Model is derived from the Shewhart Cycle in 1939. At that time, the cycle consisted of only three stages, namely specification, production and inspection. Dr. W. Edwards Deming who is a student of Dr. Walter Shewhart added another process to the cycle. In 1950, while speaking at the Japanese Union of Scientists and Engineers (JUSE) seminar, he added a fourth step for the Shewhart Cycle known as redesign through marketing research. Historians argue that the term Deming Cycle existed during the seminar (Abilla, 2014).

According to Misaki Imai, a Japanese executive took the idea of the Deming Cycle during the seminar and named it the PDCA Cycle (plan, do, check, act) in 1960. In 1986, Dr. W. Edwards Deming reintroduces the Shewhart Cycle. He said PDSA (plan, do, study, act) is more accurate than PDCA because the term 'check' means 'hold back'. The term PDSA Cycle was first used in 1993 (Norman, 2016) (Moen \& Norman, 2009).

In this study, the researchers used the PDCA Cycle as a basis and a guide in the process of designing and developing learning assessment instruments. This cycle is chosen because it is also used by the Department of Standards Malaysia. The PDCA cycle enables an organization to ensure that its processes are adequately sourced, managed and opportunities for improvement are identified and acted (Department of Standards Malaysia, 2017).

In order to develop AISNS, it involves two cycles called Cycle One and Cycle Two. Figure 2 illustrates the AISNS development process. 
INTERNATIONAL JOURNAL OF ACADEMIC RESEARCH IN BUSINESS AND SOCIAL SCIENCES Vol. 10, No. 9, 2020, E-ISSN: 2222-6990 @ 2020 HRMARS

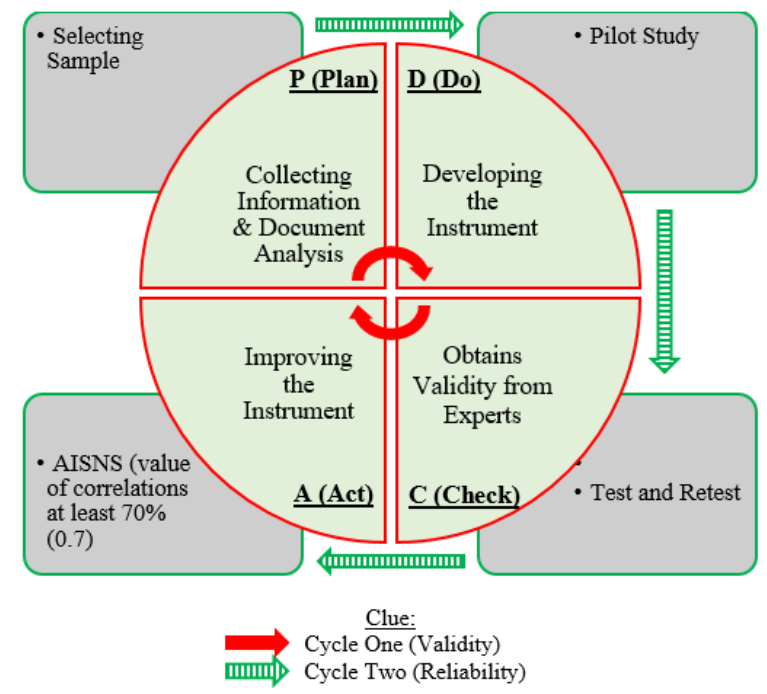

Figure 2: Developing AISNS based on PDCA Cycle

\section{Methodology}

Based on Figure 2, Cycle One is a cycle related to the AISNS development process and obtains validity from experts. The descriptions for each stage in this cycle are as follows:

\section{i.Plan}

Document analysis is performed to obtain prior information. The documents that have been referred are the Circular Letter by MOE and Examination Board, Classroom Assessment Implementation Guide 2018, Physical Education (Special Education) Text Book and Standard Document of Curriculum and Assessment on Physical Education (Special Education). Researchers have also conducted personnel communications among teachers and officials in the Perak Education Department's Special Education Unit to obtain information on physical education implementation and assessment processes. Theories such as Humanism, Constructivism and TGfU model also have been referred as a guidelines.

Field studies were also conducted to obtain information about the implementation of teaching and learning physical education among SSEN. The method of data collection is through observation and interviews.

ii.Do

After reviewing and analyze the relevant documents and theories, researchers developed the learning assessment instrument. The instrument is based on the level of performance achievement in Performance Standards. Assessment Instrument for Special Needs Students (AISNS) consist general teachers guide, daily lesson plans, test specifications tables, reinforcement questions and checklists.

\section{iii.Check}

Researchers obtain the recognition from a panel of experts on the quality of the instrument in terms of content suitability, method of assessment, technical and language of the instrument. These 
INTERNATIONAL JOURNAL OF ACADEMIC RESEARCH IN BUSINESS AND SOCIAL SCIENCES

Vol. 10, No. 9, 2020, E-ISSN: 2222-6990 @ 2020 HRMARS

experts are author of Physical Education (Special Education) textbooks Form 2, lecturers and teachers who expert in physical education and ISEP.

iv.Act

The recommendations and reviews from the experts were analyzed and instrument was refined based on that information. This process will revert to the Plan, Do and Check stage. The instrument presented to the expert panel for the second time. Data are analyzed to determine validity of the AISNS. After obtaining the suitable validity value, the researcher will move to Cycle Two.

Cycle Two is a cycle related to the process of obtaining the reliability of the AISNS. The instrument has been implemented during pilot studies. The descriptions for each stage in Cycle Two are as follows:

i.Plan

Researchers have selected a secondary school in the North Kinta district of Perak that offers ISEP to conduct pilot studies. Two teachers and students (intact sampling) have involved in this studies.

ii.Do

The AISNS is used by the teacher during teaching and learning sessions. This instrument consist daily lesson plans and the assessment takes place throughout the learning and learning (T\&L) sessions.

iii.Check

The reliability between two teachers was analyze to obtain the objectivity of the instrument. According to Sidek \& Jamaludin (2005), test and retest methods can be implemented to obtain the reliability coefficient values to see the objectivity of an instrument. Thus, researchers administered similar tests on the same group of students at different times to obtain reliability coefficients between the two testers (Ahmad, 2014).

iv.Act

The Pearson product moment correlation method was used to estimate the reliability of this assessment instrument.

\section{Analyses and Results}

The content validity of Assessment Instrument for Special Needs Students (AISNS)

The researcher has performed the process of obtaining validity for the instrument twice. Researchers obtained expert content from lecturers who has more than 20 years experience with doctoral degrees from the Department of Physical Education and Special Education Unit from Teacher's Education Institute. In addition, researcher also obtains a lecturer and author of Physical Education (Special Education) textbooks, Special Education teacher who has more than 15 years experience and two lecturers (language) with doctoral degrees from Teacher's Education Institute. Based on feedback and advice from the experts, the instrument was refined and all data about content validity was calculated using the following formula: 
INTERNATIONAL JOURNAL OF ACADEMIC RESEARCH IN BUSINESS AND SOCIAL SCIENCES

Vol. 10, No. 9, 2020, E-ISSN: 2222-6990 @ 2020 HRMARS

Total Experts Scores

$\frac{(X)}{\begin{array}{c}\text { Maximum Scores } \\ (N \times 26 \text { items })\end{array}}=\begin{gathered}\text { Content Validity } \\ \text { Achievements }\end{gathered}$

Table 1. Item Content Validity by Expert Panel $(N=6)$

\begin{tabular}{cc}
\hline Expert & $\begin{array}{c}\text { Correlation Value } \\
(\mathbf{r})\end{array}$ \\
\hline Expert 1 (Content) & 0.82 \\
Expert 2 (Content) & 0.79 \\
Expert 3 (Content) & 0.77 \\
Expert 4 (Content) & 0.77 \\
Expert 5 (Language) & 0.80 \\
Expert 6 (Language) & 0.78 \\
\hline $\mathbf{M}$ & $\mathbf{r}=\mathbf{0 . 7 9}$ \\
\hline
\end{tabular}

Table 1 shows the validity of the pilot study is $r=0.79(n=5)$. As stated in the Cycle 1 (Act), AISNS was improved according the responses, opinions and suggestions from the expert panels. The researcher gave the AISNS to five expert panels once again to determine the value of AISNS validity as well as the content item validity.

Table 2. Item Content Validity by Expert Panel ( $N=5)$

\begin{tabular}{lc}
\hline \multicolumn{1}{c}{ Expert } & $\begin{array}{c}\text { Correlation Value } \\
(\mathbf{r})\end{array}$ \\
\hline Expert 1 (Content) & 0.95 \\
Expert 2 (Content) & 0.93 \\
Expert 3 (Content) & 0.89 \\
$\begin{array}{l}\text { Expert 4 } \\
\text { (Language) }\end{array}$ & 0.87 \\
$\begin{array}{l}\text { Expert 5 } \\
\text { (Language) }\end{array}$ & 0.90 \\
\hline \multicolumn{1}{c}{$\mathbf{M}$} & $\mathbf{r}=\mathbf{0 . 9 1}$ \\
\hline
\end{tabular}

Table 2 shows that the validity of the items for Expert 1, Expert 2, Expert 3, Expert 4 and Expert 5 for AISNS is $r=0.91(n=5)$. According to Abu \& Bhasah (2008), Sidek \& Jamaludin (2005), Norkhalid, Julismah, Mohd \& Gunathevan (2015), the validity value of 0.70 is considered of having a mastery of high level.

\section{The reliability of Assessment Instrument for Special Needs Students (AISNS)}

In this study, the reliability was assessed to obtain the objectivity of the instrument. According to Sidek \& Jamaludin (2005), test and retest methods can be implemented to obtain reliability coefficient values to see the objectivity of an instrument. Researchers have administered the same test on the same students on two teachers (Ahmad, 2014). The objectivity is high when there is close 
INTERNATIONAL JOURNAL OF ACADEMIC RESEARCH IN BUSINESS AND SOCIAL SCIENCES Vol. 10, No. 9, 2020, E-ISSN: 2222-6990 @ 2020 HRMARS

agreement between two teachers. The Pearson product moment correlation method was used to estimate the reliability of the AISNS.

Pilot study was conducted to test the reliability of the instrument. It helped the researcher to get clues on which parts in the instrument that were inaccurate as well as enable the researcher to identify the problem. The corrections and improvement could be done. Pilot study was conducted to determine the value of reliability of the AISNS.

The pilot study was conducted by two Physical Education teachers and six $(n=6)$ students with SSEN. Each T\&L session lasts for 60 minutes. The teacher is required to determine the level of student achievement after the T\&L session.

Based on Table 3, the coefficient of correlation between the score with Teacher 1 and Teacher 2 is significant $(r=.963, N=6, p=.002, p<.05)$. According to Rink (2002) and Mohd, Norkhalid \& Gunathevan (2015), the value of correlations at least $70 \%(0.7)$ is sufficient and acceptable.

Table 3. The reliability of Assessment Instrument for Special Needs Students (AISNS) (N=6)

\begin{tabular}{clcc}
\hline & \multicolumn{1}{c}{ Analysis } & Teacher & Teacher \\
& & 1 & 2 \\
\hline Teacher & Pearson & 1 & $.963\left(^{* *}\right)$ \\
1 & Correlation & & \\
& Sig. (2-tailed) & & .002 \\
& $\mathrm{~N}$ & 6 & 6 \\
Teacher & Pearson & $.963\left(^{* *}\right)$ & 1 \\
2 & Correlation & & \\
& Sig. (2-tailed) & .002 & \\
& $\mathrm{~N}$ & 6 & 6 \\
\hline
\end{tabular}

** correlation is significant at the 0.01

\section{Conclusion}

Based on the findings, the Assessment Instrument for Special Needs Students is suitable to be used as a standardized assessment instrument to assess the level of Performance Standard for basic skills of invasion category games in Physical Education (Special Education) for Form 2. It is expected that this learning assessment instrument will be a more realistic and holistic assessment instrument and can measure the level of students mastery in line with School-Based Assessment requirements as outlined in the Malaysia Education Development Plan 2013 - 2025.

\section{Contribution of Study}

The basic elements of assessment used in AISNS can help teachers to understand and subsequently master the skills of performing classroom assessment. Such things are indirectly able to contribute towards the ministry's desire to transform the teaching profession into a profession of choice. The increase in the level of professionalism of teachers, especially in the field of reaching and learning can indirectly be used as a reference by school administrators in the process of evaluating teachers as excellent teacher candidates and also annual performance evaluation. Administrators can make 
INTERNATIONAL JOURNAL OF ACADEMIC RESEARCH IN BUSINESS AND SOCIAL SCIENCES

Vol. 10, No. 9, 2020, E-ISSN: 2222-6990 @ 2020 HRMARS

this assessment instrument as a reference document and performance index in the assessment of the teaching process of teachers.

In addition, this study can be used as a guide for teachers to plan and build assessment instruments as stated in the circular letter. The construction of a good assessment instrument can increase the effectiveness of the assessment made. The instruments built in this study can also be used directly or as a guide in the implementation of teaching and learning sessions as long as there are no changes and updates in syllabus.

This assessment instrument is suitable as a guide for teachers in the process of making student learning assessment holistically. This guided guide can indirectly help teachers determine students' level of mastery based on performance standards. Student performance standard reports can help parents and guardians know the development and achievement of their children from time to time.

\section{References}

Abilla, P. (2014). PDCA Cycle or PDSA Cycle - Which is Right? Accessed from https://www.shmula.com/pdca-cycle-or-pdsa-cycle-which-is-right/13653/

Abu Bakar, N., \& Bhasah, A. B. (2008). Penaksiran dalam pendidikan dan sains sosial. Tanjong Malim: Universiti Pendidikan Sultan Idris.

Hashim, A. (2014). Panduan analisis data secara efisien. Selangor: Dubook Press Sdn. Bhd

Arsaythamby, V., Hariharan, N., K \& Ruzlan Md-Ali. (2015). Teachers' Knowledge and Readiness Towards Implementation of School Based Assessment in Secondary Schools. International Education Studies, 8(11), 193-203. doi:10.5539/ies.v8n11p193

Curriculum Development Division. (2018). Panduan Pelaksanaan Pentaksiran Bilik Darjah. Putrajaya: Kementerian Pendidikan Malaysia

Curriculum Development Division. (2016). Kurikulum Standard Sekolah Menengah Pendidikan Khas. Pendidikan Jasmani dan Pendidikan Kesihatan. Dokumen Standard Kurikulum dan Pentaksiran Tingkatan 2. Putrajaya: Kementerian Pendidikan Malaysia

Department of Standards Malaysia. (2017). Malaysian Standard MS ISO 9001:2015. Sistem Pengurusan Kualiti - Keperluan (Semakan Kedua). Cyberjaya: Kementerian Sains, Teknologi dan Inovasi.

Abdul Khalil, F., \& Awang, M. I. (2016). Isu Kesediaan Guru dalam Amalan Melaksanakan Pentaksiran Berasaskan Sekolah. EDUCATUM-Journal of Social Science, 2(2016), 1-7

Jani, J., \& Ali, S. K. S. (2012). Ilmu Konten Pedagogi dengan Pelaksanaan Pengajaran Guru dalam Pendidikan Jasmani di Sekolah Menengah Malaysia-Indonesia. Jurnal Sains Sukan dan Pendidikan Jasmani. May 2012, 1-13. Accessed from https://ejournal.upsi.edu.my/GetFinalFile.ashx?file= fd58d3e5-55aa96ca-6e39fe79f7e6.pdf

Saad, L. (2017). Pentaksiran Pembelajaran Kemahiran Asas Bagi Permainan Kategori Serangan Dalam Pendidikan Jasmani Tahun 4. Tesis Ijazah Doktor Falsafah

Malaysian Examinations Board. (2014). Kajian Pelaksanaan PBS: Dokumen Standard Prestasi. Kuala Lumpur: Lembaga Peperiksaan Malaysia

Malaysian Examinations Board. (2013). Kajian PBS: Kefahaman dan Amalan Guru. Kuala Lumpur: Lembaga Peperiksaan Malaysia 
INTERNATIONAL JOURNAL OF ACADEMIC RESEARCH IN BUSINESS AND SOCIAL SCIENCES

Vol. 10, No. 9, 2020, E-ISSN: 2222-6990 @ 2020 HRMARS

Ministry of Education Malaysia. (2013). Pelan Pembangunan Pendidikan Malaysia 2013-2025: Pendidikan Prasekolah hingga Lepas Menengah. Putrajaya: Kementerian Pendidikan Malaysia

Moen, R., \& Norman, C. (2009). Evolution of the PDCA cycle. Accessed from https://www.researchgate.net/publication/228475044_Evolution_of_the_PDCA_cycle

Shahril, M. I., Salimin, N., \& Elumalai, G. (2015). The Validity and Reliability of ISO Test towards the Performance Assessment of Future Physical Education Teachers in Teaching and Learning Process. Procedia - Social and Behavioral Sciences. 195, 814-820. doi: 10.1016/j.sbspro.2015.06.184

Ishak, N. (2011). School based assessment as transformation in educational asessment. Keynote in International Seminar On Measurement and Evaluation (ICMEE 4) Universiti Sains Malaysia, Pulau Pinang, 9-12 October

Norkhalid S., Julismah J., Izwan, M. S., \& Gunathevan, E. (2015). Validity and reliability of comprehensive assessments for handball and badminton games in physical education. Asian Social Science, 11(23), 12-21.

Norman, C. L. (2016, February 10). Evolution of PDSA and the Difference Between PDSA and PDCA. Diakses daripada https://asqaustin.org/wp-

content/uploads/2015/12/History_of_the_PDSA_Cycle_CN_ASQ_Talk-_2_10_2016_Handout.pdf

Rink, J. E. (2002). Teaching physical education for learning (4th ed.). New York: McGraw Hill.

Noah, S. M., \& Ahmad, J. (2005). Pembinaan modul. Bagaimana membina modul latihan dan modul akademik. Selangor: Universiti Putra Malaysia

Special Education Division. (2015). Buku Panduan Pengoperasian Program Pendidikan Khas Integrasi. Putrajaya: Kementerian Pendidikan Malaysia

Special Education Unit. (2018). List of School Information. Ipoh, Perak: State Education Department. 